\title{
Nitrogen fertilization in consecutive cycles and its impact on high-density peach crops
}

\author{
Letícia Vanni Ferreira ${ }^{(1)}$, Luciano Picolotto(2), Ivan dos Santos Pereira(3), \\ Juliano Dutra Schmitz ${ }^{(4)}$ and Luis Eduardo Corrêa Antunes ${ }^{(1)}$
}

\begin{abstract}
(1)Embrapa Clima Temperado, Rodovia BR-392, Km 78, Caixa Postal 403, CEP 96001-971 Pelotas, RS, Brazil. E-mail: letivf@hotmail.com, luis.antunes@embrapa.br (2)Universidade Federal de Santa Catarina, Caixa Postal 101, CEP 89520-000 Curitibanos, SC, Brazil. E-mail: picolotto.I@ufsc.br ${ }^{(3)}$ Universidade Federal dePelotas, CaixaPostal354, CEP 96010-900 Pelotas, RS, Brazil.E-mail: ivanspereira@gmail.com (4)Instituto Federal Catarinense, Campus Concórdia, Rodovia SC-283, Km 08, Caixa Postal 58, CEP 89703-720 Concórdia, SC, Brazil. E-mail: juliano.schmitz@ifc.edu.br
\end{abstract}

\begin{abstract}
The objective of this work was to evaluate the effect of nitrogen fertilization on the mineral composition of leaves, initial growth, and yield of peach (Prunus persica) tree advanced selections grown at a high-planting density. The experiment was carried out between 2012 and 2015 in a randomized complete block design, with a combination of advanced selections of the 'Cascata 1513' and 'Cascata 1067' peach trees and of $\mathrm{N}$ fertilization doses $\left(0,30,60\right.$, and $\left.120 \mathrm{~kg} \mathrm{ha}^{-1} \mathrm{~N}\right)$. Green weight after pruning, diameter, and increase of trunk diameter, canopy volume, plant height, branch length, number of buds per centimeter of shoot, chlorophyll index, leaf area, rust incidence, average production, number of fruit, and mass of fruit were evaluated. Genotype affects the vegetative growth and productive performance of peach trees. The application of $\mathrm{N}$ to dense peach orchards promotes a greater vegetative growth of the plants and increases the content of the nutrient in leaves. The initial production is affected by $\mathrm{N}$ fertilization. The recommendation of $\mathrm{N}$ fertilization made to date is insufficient for peach trees at high-density management systems of production.
\end{abstract}

Index terms: Prunus persica, growth, nitrogen, nutrition, planting density.

\section{Adubação nitrogenada em ciclos consecutivos e seu impacto no manejo adensado de pessegueiro}

Resumo - O objetivo deste trabalho foi avaliar o efeito da adubação nitrogenada na composição mineral das folhas, no crescimento inicial e na produção inicial de seleções avançadas de pessegueiro (Prunus persica) cultivadas em alta densidade de plantio. O experimento foi conduzido entre 2012 e 2015 em delineamento em blocos ao acaso, com a combinação de seleções avançadas de pessegueiro 'Cascata 1513' e 'Cascata 1067' e de doses de adubação nitrogenada $\left(0,30,60\right.$ e $120 \mathrm{~kg} \mathrm{ha}^{-1}$ de $\left.\mathrm{N}\right)$. A massa de poda, diâmetro e incremento do diâmetro de tronco, volume de copa, altura de plantas, comprimento de ramos, número de gemas por centímetro de ramo, índice de clorofila, área foliar, incidência de ferrugem, produção média e o número e a massa de frutos foram avaliados. O genótipo influencia o crescimento vegetativo e o desempenho produtivo do pessegueiro. A aplicação de $\mathrm{N}$ em pomares adensados promove maior crescimento vegetativo das plantas e aumenta o teor do nutriente nas folhas. A produção inicial é influenciada pela adubação nitrogenada. A recomendação de adubação nitrogenada feita até o presente é insuficiente para pessegueiros conduzidos em sistemas de produção adensada.

Termos para indexação: Prunus persica, crescimento, nitrogênio, nutrição, densidade de plantio.

\section{Introduction}

Orchard nutrition is a major factor affecting productivity and requires a balanced nutrient supply that should be achieved by fertilizer supplementation (Amorim et al., 2015). However, the addition of fertilization products should only be considered when it is economically feasible (Freire \& Magnani, 2014).
Peach growers in the state of Rio Grande do Sul have adopted higher-planting density systems, aiming at the increase of crop yield starting in the first year (Mayer \& Pereira, 2012). During the last decade, planting density went from being low (400-700 plants per hectare) to high, reaching between 1,000 and 1,500 plants per hectare (Loreti \& Massai, 2006). 
Although low and medium densities of peach tree planting are still predominant worldwide, higher-planting density is a trend in countries such as Slovenia, Italy, South Africa, and United States, with more than 1,300 plants per hectare (Loreti \& Massai, 2002, 2006; Marini \& Reighard, 2008). One of the effects of high-density planting is a greater competition for nutrients among plants, which affects fertilizer requirements and application recommendations.

The current fertilizer recommendations for peach tree crops do not yet take into consideration the increased planting density of this crop, and consider only soil organic matter content in relation to the orchard age. The amount of fertilizer recommended by the fertilizer and liming guidelines for the states of Rio Grande do Sul and Santa Catarina (Manual..., 2016) is 20 to $80 \mathrm{~kg} \mathrm{ha}^{-1} \mathrm{~N}$ per year. These guidelines provide recommendations on fertilization for populations of up to 400 plants per hectare. There is no guidance regarding $\mathrm{N}$ dose that should be applied in an orchard with a higher density of plants. According to Sete et al. (2015), the $\mathrm{N}$ accumulated in the plants throughout crop seasons contributes to increase peach tree yield.

Given the low-mean yield of peach trees in the state of Rio Grande do Sul, the scarcity of adequate guidance, and the rationale for different fertilizer recommendations in high-density orchards, it is presumed that high-density planting requires the use of higher doses of $\mathrm{N}$ than those recommended in the Manual... (2016).

The objective of this work was to evaluate the effect of nitrogen fertilization on the mineral composition of leaves, initial growth, and yield of peach tree advanced selections grown at a high-planting density.

\section{Materials and Methods}

The experiment was conducted in field conditions, from August 2012 to 2016 in the experimental area of Embrapa Clima Temperado, in the municipality of Pelotas, in the state of Rio Grande do Sul, at $31^{\circ} 40^{\prime} 41^{\prime \prime S}, 52^{\circ} 26^{\prime} 22^{\prime \prime} \mathrm{W}$, and $70 \mathrm{~m}$ altitude. According to the Köppen-Geiger's classification, the climate of the region is of Cfa type, that is, humid with hot summers. Rainfall and air temperature data during the experimental period are shown in Figure 1. The soil is moderately deep, with an intermediate texture in the A-horizon, and clayey texture in the B-horizon, classified as a Latossolo Vermelho-Amarelo (Santos et al., 2006), i.e., a Typic Haplustox.

The spacing adopted between plants was $1.5 \times 5.0 \mathrm{~m}$, with a planting density of 1,333 plants per ha. The 'Capdeboscq' rootstock was used for grafting the scions 'Cascata 1513' and 'Cascata 1067' - which are advanced selections of the genetic improvement program of Embrapa Clima Temperado, both of which have the potential to be marketed because of their intense red color that is appealing to consumers. 'Cascata 1067' is very productive and bears large-sized fruit. 'Cascata 1513' bears smaller fruit, but has a typical crunchiness, which is preferred by the consumers, and is grown in a y-shaped training system.

Soil samples from the $0-20 \mathrm{~cm}$ depth layer of the experimental area were collected in 2012 and analyzed according to Manual..., (2016), indicating: $4.6 \mathrm{pH}$ in $\mathrm{H}_{2} \mathrm{O}$ (considered very low); $3.4 \mathrm{cmol}_{\mathrm{c}} \mathrm{dm}^{-3} \mathrm{H}+\mathrm{Al}$ (low); $13 \mathrm{~g} \mathrm{~kg}^{-1}$ organic matter; $1.4 \mathrm{cmol}_{\mathrm{c}} \mathrm{dm}^{-3} \mathrm{Ca}$ (low); $1.4 \mathrm{cmol}_{\mathrm{c}} \mathrm{dm}^{-3} \mathrm{Mg}$ (high); $17.9 \mathrm{mg} \mathrm{dm}^{-3} \mathrm{P}$ (intermediate); and $75.0 \mathrm{mg} \mathrm{dm}^{-3} \mathrm{~K}$ (high).

Pre-planting liming and fertilization with $\mathrm{P}$ and $\mathrm{K}$ were performed according to the fertilizer and liming guidelines. Liming was performed three months before planting the seedlings, in May 2012, and pre-planting fertilization was performed one month before planting, in July 2012. The soil received 130 $\mathrm{kg} \mathrm{ha}^{-1} \mathrm{P}_{2} \mathrm{O}_{5}$ and $30 \mathrm{~kg} \mathrm{ha}^{-1} \mathrm{~K}_{2} \mathrm{O}$ (Manual..., 2016), and orchard management was performed according to the standards for integrated peach tree production (Fachinello et al., 2003). Nitrogen fertilization for the growth period was provided during the first three years of the orchard establishment $(2012,2013$, and 2014). Increasing doses of $\mathrm{N}\left(0,30,60\right.$, and $120 \mathrm{~kg} \mathrm{ha}^{-1}$ $\mathrm{N})$ were applied at three different times (August, November, and February) each year. Urea containing $45 \% \mathrm{~N}$ was used as the fertilizer source.

The following plant variables were analyzed during the years 2013, 2014, and 2015: green weight after pruning, that is the weight of the material removed from the two central plants of the plots, during two separate pruning times (summer and winter pruning), expressed as grams per plant; trunk diameter, which was obtained from two measurements, taken with a digital pachymeter at $20 \mathrm{~cm}$ height above the soil, in the two central plants of the plot; trunk diameter increase, which is the difference in diameter between the first and the second year, and the difference between the 
first and the last year; canopy volume, which was measured in three central plants of the plots and calculated according to the method described by Rossi (2004), using the equation $\mathrm{V}=[(\mathrm{L} / 2) \times(\mathrm{E} / 2) \times \mathrm{A} \times \pi] / 3$, in which $\mathrm{V}$ is the volume of the canopy, $\mathrm{L}$ is the distance between the main branches, $\mathrm{E}$ is the mean thickness of the main branches, and A is the height of the canopy; plant height, which was measured from soil level to the tip of the plant $(\mathrm{cm})$; branch length, obtained by calculating the mean length $(\mathrm{cm})$ of two productive branches per plant, which were randomly selected from the middle part of the canopy of two central plants of the plots; number of buds per centimenter, obtained by calculating the ratio between the branch length $(\mathrm{cm})$ and the number of buds (vegetative and flowering); total chlorophyll index, which was measured using a chlorophyll meter ClorofiLOG (Falker Automação Agrícola Ltda., Porto Alegre, RS, Brazil); and specific leaf area and rust incidence caused by Tranzschelia discolor (Fuckel) Tranzschel and Litv., obtained from a sample comprising 20 leaves matured by treatment and removed from the middle third of the canopy.

Yield variables were assessed in 2013, 2014, and 2015 , after the establishment of the orchard. They were obtained by collecting and weighing the fruit produced by the two central plants of each plot; mean fruit mass (estimated by dividing the total mass of the fruit in each plant by the number of fruit collected per plant), and number of fruit per plant (obtained by counting the fruit collected per plant).

The experiment used a randomized block design (RBD) with subdivided plots according to a $2 \times 4$ factorial arrangement, that is, two genotypes ('Cascata 1067' and 'Cascata 1513') and four $\mathrm{N}$ doses $(0,30,60$, and $120 \mathrm{~kg} \mathrm{ha}^{-1} \mathrm{~N}$ ), with four replicates of four plants. The results were subjected to the analysis of variance, and the Tukey's test was performed, at 5\% probability. The statistical analyses were performed using the Sisvar software, version 5.1 (Ferreira, 2014).

\section{Results and Discussion}

Nitrogen doses promoted a linear increase of green weight after pruning, trunk diameter, branch length, canopy volume, and plant height of the assessed peach genotypes (Figures 2 A, B, C, D, and E). These results were similar to those observed by Dias et al. (2012) and Della Bruna \& Back (2014), who reported that increasing doses of $\mathrm{N}$ led to an increase of vegetative development.

According to Nunes et al. (2008), maximal $\mathrm{N}$ in plant contributes to the increase of plant height, trunk diameter, and fresh biomass of the aerial parts. Nitrogen

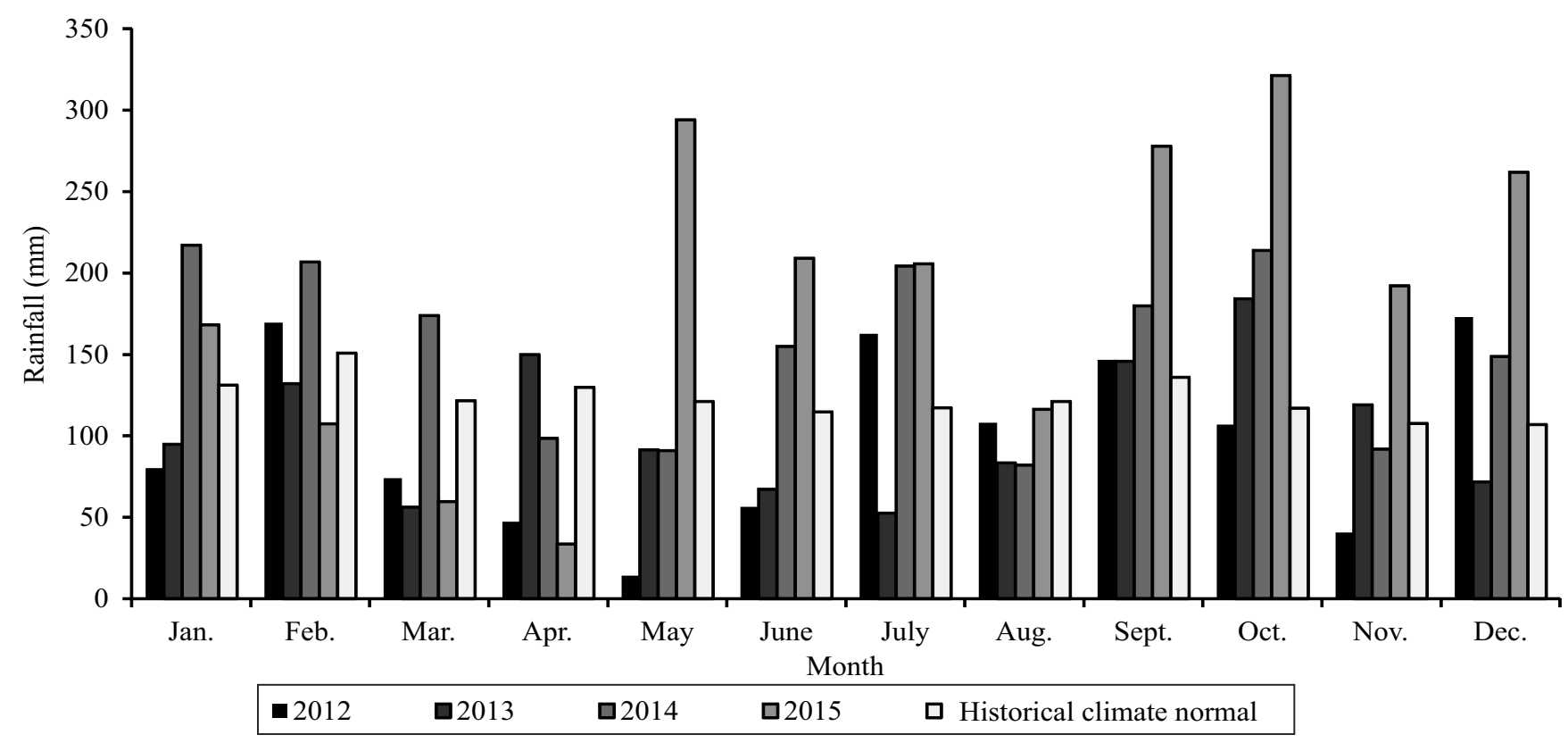

Figure 1. Average monthly precipitation, sum of months in the years in which the experiment was conducted, and historical climate normals, located in the municipality of Pelotas, RS, Brazil. 
is considered the most important nutrient for peach tree (Ferreira et al., 2016) and it is required in large amounts (Pereira et al., 2015). According to Rombolà et al. (2012), assimilation of mineral nutrients by young plants is essential during the early establishment of the orchard, particularly, for the growth of the trees. Additionally, the recommended $\mathrm{N}$ dose for a specific region should take into account the density of plants in the orchard, among other aspects (Ferreira et al., 2016).

The number of vegetative buds per centimeter of branch was not affected by any of the studied factors (Figure 2F), which is in agreement with the observations reported by Della Bruna \& Back (2014). These authors also did not find differences in the number of vegetative buds between the treatments involving different doses of $\mathrm{N}$ to Aurora and Chimarrita cultivars in southern Santa Catarina.

The scion Cascata 1067 cultivar had a higher chlorophyll index than Cascata 1513 during the study period(Table 1). This factindicates that one of the studied genotypes has a greater photosynthetic capacity; it may also explain the increase of its vegetative growth, which was evident from a higher-green weight after pruning, canopy volume, trunk diameter, plant height, branch length, and buds per centimeter of branch (Table 2). When N dose was increased only in 2013, the chlorophyll index was positively impacted, and a direct linear relationship was observed (Figure $2 \mathrm{H}$ ). These results are in agreement with that reported by Leal et al. (2007). Furthermore, the chlorophyll content also positively correlates with $\mathrm{N}$ doses (Pereira et al., 2015). This is partly because $\mathrm{N}$ is a component of the chlorophyll molecule (Leonardo et al., 2013; Taiz \& Zeiger, 2013). Leaf area between the assessed genotypes were comparable, however, it increased in both cultivars with increasing $\mathrm{N}$ application (Table 1). Similar results were obtained by Guarçoni \& Ventura (2011), who reported that the increase of the $\mathrm{N}$ amount led to an increase of leaf length. According to Medeiros et al. (2004), the addition of $\mathrm{N}$ promotes cell division, and it is involved in growth and development (Oliveira et al., 2015).

During the study period in 2014 and 2015, no changes in the chlorophyll index was observed across all $\mathrm{N}$ treatments. The absence of any effect may be attributed to a higher consumption of $\mathrm{N}$ which resulted in a higher yield in 2014, or to drainage of nutrients, or even to an increased output of $\mathrm{N}$ in the fruit. Therefore, the chlorophyll index remained unchanged even at the highest doses of N. According to Leal et al. (2007), $\mathrm{N}$ is a component of chlorophyll molecule and is required for photosynthesis. These authors state that, in the absence of $\mathrm{N}$, the chlorophyll photosynthesis is affected. The lack of energy production impacts some vital functions, such as the absorption of nutrients and the production of carbohydrates that are necessary for the reproductive development.

There were no differences between the genotypes for change in trunk diameter, during the years 2014 and 2015 (Table 2); however, a proportionate increase in this parameter was observed when $\mathrm{N}$ application was increased (Figure $2 \mathrm{~B}$ ). This result is similar to those obtained by Nunes et al. (2008), who observed that the increase of $\mathrm{N}$ content in the tissues of grafted plants onto the 'Aldrighi' rootstock led to a increase of trunk diameter. Rocha et al. (2007) suggested that this variable is related to the capacity of the rootstock to impact plant vigor, which in turn may be related to the capacity of the rootstock to absorb available $\mathrm{N}$ in the soil.

Both studied cultivars did not have any effect on the severity of peach rust at all doses of $\mathrm{N}$ tested (Table 1). Interestingly, this finding contradicts Dolinski et al. (2012), who reported that the severity of rust reduced due to $\mathrm{N}$ fertilization, that is, peach plants treated with the highest doses of $\mathrm{N}$ (183 and $240 \mathrm{~kg} \mathrm{ha}^{-1}$ ) had the lowest levels of peach rust severity, during the 2009/2010 and 2010/2011 crop seasons.

In the first two years (2013 and 2014) of yield assessment, 'Cascata 1513' had the highest yield potential initially - the highest means for yield per plant (MYP), number of fruit per plant (NFP), and mean fruit mass (MFM) (Table 2). Yield variation between cultivars is common in orchards (Alves et al., 2012; Souza et al., 2013).

In 2013, the crop yield exhibited a quadratic response to the applied doses of $\mathrm{N}$, with an estimated maximum, effective dose of $69 \mathrm{~kg} \mathrm{ha}^{-1} \mathrm{~N}$ (Figure $3 \mathrm{~A}$ ), which is $19 \mathrm{~kg}$ more than the recommended dose (of $50 \mathrm{~kg} \mathrm{ha}^{-1} \mathrm{~N}$ ) required for the growth phase during the first year after planting peach. This result is in agreement with that of Dolinski et al. (2012), who also reported that the increasing amounts of $\mathrm{N}$ application resulted in a proportionate increase of yield. According to Leal et al. (2007), $\mathrm{N}$ affects photosynthesis and, therefore, $\mathrm{N}$ deficiency can impact photosynthesis and 

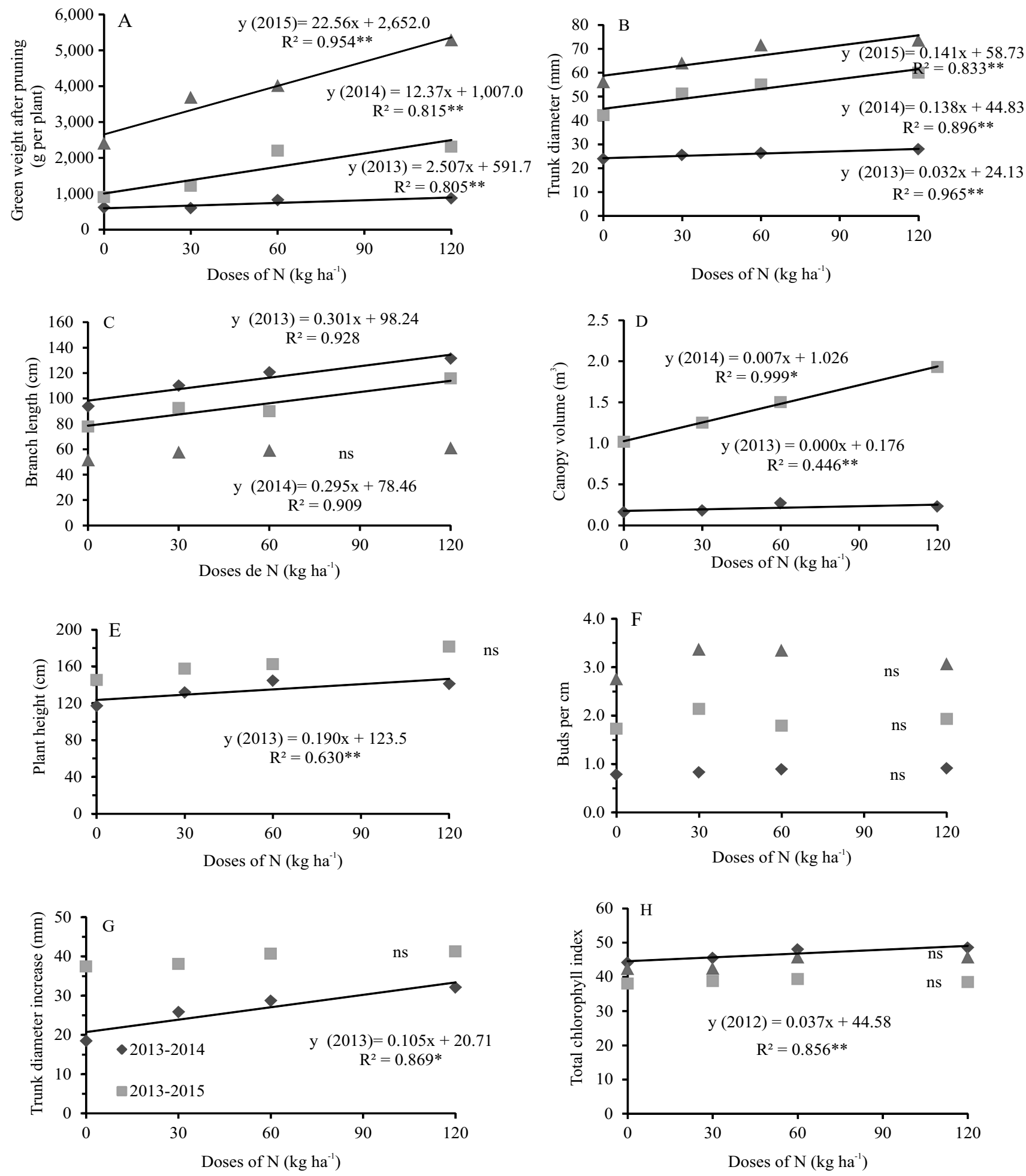

\section{$\checkmark 2013 \square 2014 \triangle 2015$}

Figure 2. Green weight after pruning (A), trunk diameter (B), branch length (C), canopy volume (D), plant height (E), number of buds per centimeter (F), increase of trunk diameter (G), and total chlorophyll index (H) of tree peach (Prunus persica) genotypes subjected to different doses of $\mathrm{N}$ fertilization in 2013, 2014, and 2015. *, **, and ***Significant by the

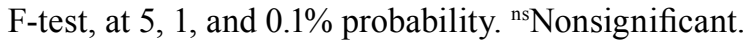


other physiological events in plants. Any reduction of the photosynthesis translates as a reduced growth, delayed or no flowering, and this facts reduce yield. Therefore, $\mathrm{N}$ is one of the nutrients that promotes significant morphophysiological changes in plants.

Furthermore, crop yield depends on other factors, such as precipitation at the time of fertilization, as emphasized in the study conducted by Fidalski \& Auler (2007). During the years 2014 and 2015, a direct relationship between $\mathrm{N}$ increase and yield increase was observed (Figure $3 \mathrm{~A}$ ). This result highlights the need to apply at least $120 \mathrm{~kg} \mathrm{ha}^{-1} \mathrm{~N}$, that is, twice as high as the currently recommended dose $\left(60 \mathrm{~kg} \mathrm{ha}^{-1}\right)$ in the second year after plantation (2014), and $40 \mathrm{~kg} \mathrm{ha}^{-1}$ as high as what is currently recommended $\left(80 \mathrm{~kg} \mathrm{ha}^{-1}\right.$ $\mathrm{N}$ ) in the third year after plantation (2015), for plants to achieve their yield potential. According to Leal et al. (2007), there is a window of nutritional deficiency in which the plant yield tends to increase as a consequence of $\mathrm{N}$ supply.

Table 1. Trunk diameter increase (TDI), total clorophyll index, total leaf area, severity of rust incidence by Tranzschelia discolor, area and healthy leaf area (LA) of 'Cascata 1513' and 'Cascata 1067' peach (Prunus persica) tree genotypes subjected to different doses of $\mathrm{N}$ fertilization growth ${ }^{(1)}$.

\begin{tabular}{|c|c|c|c|c|c|c|c|c|}
\hline \multirow[t]{2}{*}{ Variable } & \multirow[t]{2}{*}{$\begin{array}{l}\text { TDI (mm) } \\
2013 / 2014\end{array}$} & \multirow[t]{2}{*}{$\begin{array}{l}\text { TDI (mm) } \\
2013 / 2015\end{array}$} & \multirow[t]{2}{*}{$\begin{array}{l}\text { Clorophyll } \\
\text { index } 2013\end{array}$} & \multirow[t]{2}{*}{$\begin{array}{l}\text { Clorophyll } \\
\text { index } 2014\end{array}$} & \multirow[t]{2}{*}{$\begin{array}{l}\text { Clorophyll } \\
\text { index } 2015\end{array}$} & $\begin{array}{r}\text { Total leaf } \\
\text { area }\left(\mathrm{cm}^{2}\right) \\
\end{array}$ & $\begin{array}{c}\text { Healthy leaf } \\
\text { area }\left(\mathrm{cm}^{2}\right)\end{array}$ & $\begin{array}{c}\text { Severity (\% of } \\
\text { injured LA) } \\
\end{array}$ \\
\hline & & & & & & -------------- & --------2016 & '-------------- \\
\hline \multicolumn{9}{|l|}{ Genotype } \\
\hline Cascata 1067 & $26.46^{\mathrm{ns}}$ & $39.25^{\text {ns }}$ & $48.23 \mathrm{a}$ & $39.08^{\mathrm{ns}}$ & $44.12 \mathrm{a}$ & $15.70^{\mathrm{ns}}$ & $89.81^{\mathrm{ns}}$ & $19.19^{\mathrm{ns}}$ \\
\hline Cascata 1513 & 26.06 & 40.51 & $45.07 \mathrm{~b}$ & 38.25 & $43.86 \mathrm{~b}$ & 15.15 & 82.88 & 17.11 \\
\hline \multicolumn{9}{|l|}{$\mathrm{N}$ dose $\left(\mathrm{kg} \mathrm{ha}^{-1}\right)$} \\
\hline 0 & $18.45 b$ & $37.47^{\mathrm{ns}}$ & $44.16 b$ & $38.07^{\mathrm{ns}}$ & $42.26^{\text {ns }}$ & $12.30 \mathrm{~b}$ & $80.59^{\text {ns }}$ & $19.40 \mathrm{~b}^{\mathrm{ns}}$ \\
\hline 30 & $25.80 \mathrm{ab}$ & 38.08 & $45.49 \mathrm{~b}$ & 38.75 & 42.33 & $14.07 \mathrm{ab}$ & 83.44 & 16.55 \\
\hline 60 & $28.71 \mathrm{ab}$ & 42.69 & $47.99 a$ & 39.34 & 45.67 & $16.50 \mathrm{ab}$ & 84.35 & 15.64 \\
\hline 120 & $32.10 \mathrm{a}$ & 41.27 & $48.55 \mathrm{a}$ & 38.48 & 45.70 & $18.82 \mathrm{a}$ & 78.98 & 21.01 \\
\hline CV (\%) & 29.32 & 23.38 & 3.86 & 6.54 & 6.07 & 18.95 & 6.94 & 31.27 \\
\hline
\end{tabular}

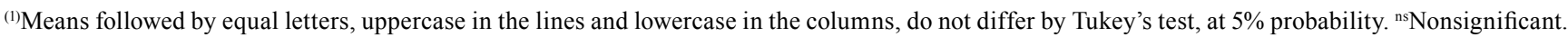
$\mathrm{CV}$, coefficient of variation.

Table 2. Green weight after pruning (GWP), canopy volume (CV), trunk diameter (TD), plant height (PH), branch length (BL), buds per $\mathrm{cm}$, average production per plant (AVP), average number of fruit per plant (NMP), and mean fruit mass (MMF) of peach trees (Prunus persica) genotypes subjected to different doses of nitrogen fertilization in the years of 2013, 2014, and $2015^{(1)}$.

\begin{tabular}{|c|c|c|c|c|c|c|c|c|c|}
\hline Genotype & $\begin{array}{c}\text { GWP } \\
\text { (g per plant) }\end{array}$ & $\begin{array}{l}\mathrm{CV} \\
\left(\mathrm{m}^{3}\right)\end{array}$ & $\begin{array}{c}\mathrm{TD} \\
(\mathrm{mm}) \\
\end{array}$ & $\begin{array}{l}\mathrm{PH} \\
(\mathrm{cm}) \\
\end{array}$ & $\begin{array}{l}\mathrm{BL} \\
(\mathrm{cm}) \\
\end{array}$ & $\begin{array}{l}\text { Buds per } \\
\text { centimeter }\end{array}$ & $\begin{array}{c}\text { AVP } \\
\text { (g per plant) }\end{array}$ & ANP & $\begin{array}{c}\text { AMP } \\
\text { (g per fruit) }\end{array}$ \\
\hline & & & & & 2013 & & & & \\
\hline Cascata 1067 & $822.78 \mathrm{a}$ & $0.25 \mathrm{a}$ & $26.67 \mathrm{a}$ & $145.87 \mathrm{a}$ & $125.82 \mathrm{a}$ & $0.87^{\mathrm{ns}}$ & $80.72 b$ & $0.97 b$ & $40.51 \mathrm{~b}$ \\
\hline Cascata 1513 & $635.18 \mathrm{~b}$ & $0.17 \mathrm{~b}$ & $25.03 b$ & $121.17 \mathrm{~b}$ & $103.84 \mathrm{~b}$ & 0.83 & $468.24 \mathrm{a}$ & $7.47 \mathrm{a}$ & $60.05 \mathrm{a}$ \\
\hline \multirow[t]{2}{*}{ CV (\%) } & 27.98 & 32.26 & 8.57 & 9.27 & 16.04 & 13.86 & 49.05 & 48.35 & 48.45 \\
\hline & & & & & 2014 & & & & \\
\hline Cascata 1067 & $1656.89^{\mathrm{ns}}$ & $1.64 \mathrm{a}$ & $53.14^{\mathrm{ns}}$ & $170.72 \mathrm{a}$ & $91.25^{\mathrm{ns}}$ & $1.88^{\mathrm{ns}}$ & $7152.87^{\mathrm{ns}}$ & $72.31 \mathrm{~b}$ & $100.60 \mathrm{a}$ \\
\hline Cascata 1513 & 1449.76 & $1.21 \mathrm{~b}$ & 51.09 & $152.72 \mathrm{~b}$ & 96.70 & 1.92 & 8758.84 & $187.84 \mathrm{a}$ & $44.91 \mathrm{~b}$ \\
\hline \multirow[t]{2}{*}{ CV (\%) } & 29.07 & 28.24 & 17.12 & 13.39 & 12.25 & 24.59 & 37.05 & 39.52 & 16.27 \\
\hline & & & & & 2015 & & & & \\
\hline Cascata 1067 & $4760.56 \mathrm{a}$ & - & $65.72^{\mathrm{ns}}$ & - & $57.76^{\mathrm{ns}}$ & $2.77^{\mathrm{ns}}$ & $3656.63 \mathrm{a}$ & $31.51 \mathrm{a}$ & $116.91 \mathrm{a}$ \\
\hline Cascata 1513 & $2912.90 \mathrm{~b}$ & - & 66.57 & - & 56.64 & 3.48 & $919.54 b$ & $12.84 \mathrm{~b}$ & $69.66 \mathrm{~b}$ \\
\hline CV (\%) & 43.83 & - & 14.92 & - & 17.47 & 35.61 & 31.72 & 32.04 & 14.61 \\
\hline
\end{tabular}

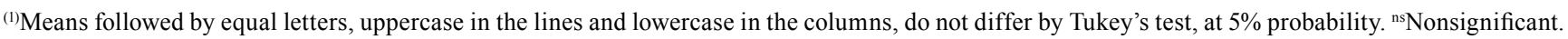
$\mathrm{CV}$, coefficient of variation. 

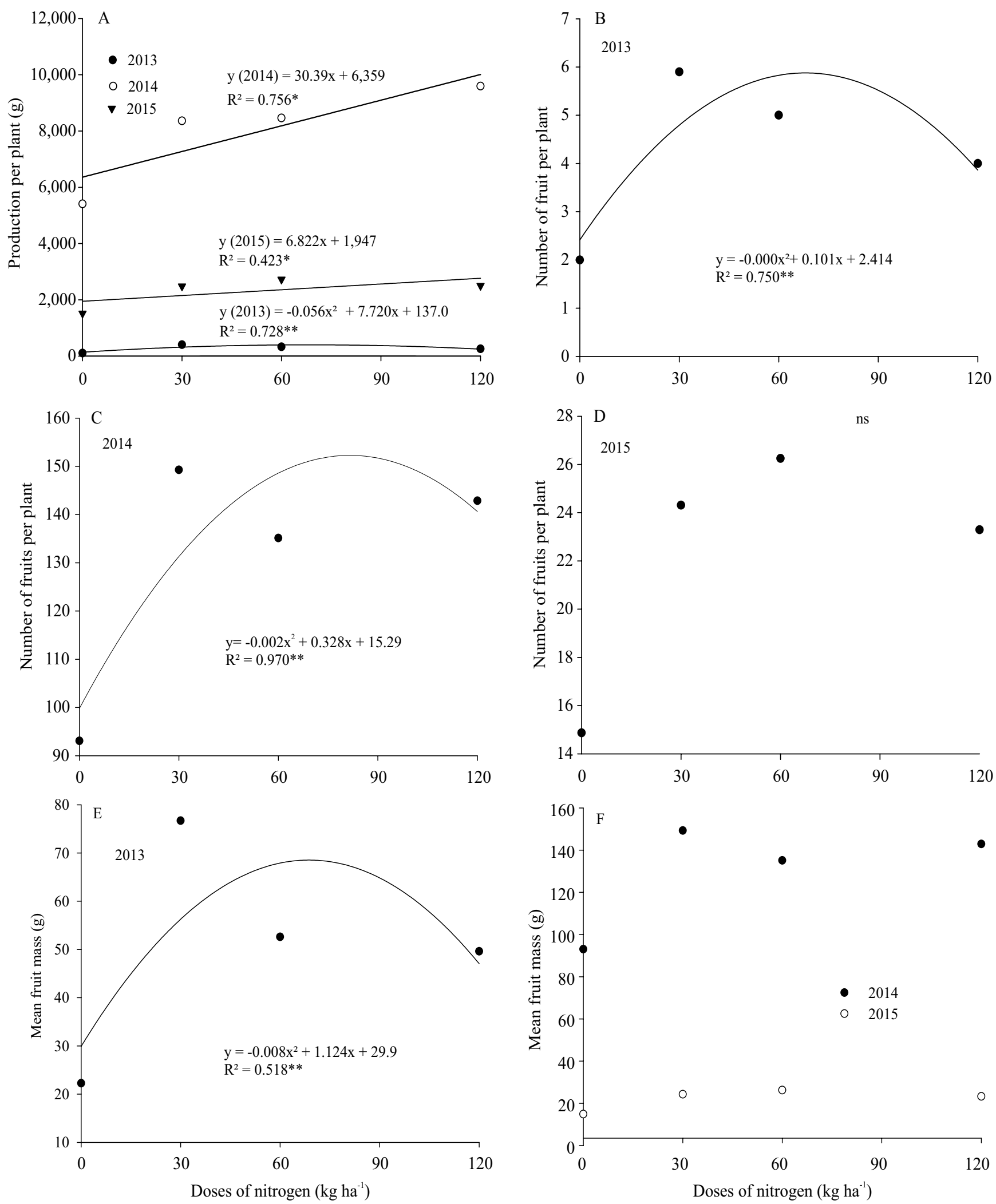

Figure 3. Average production per plant (A), number of fruit per plant (B, C, and D), and mean fruit mass of 'Cascata 1513' and 'Cascata 1067' peach (Prunus persica) trees in 2013 (E), and 2014 and 2015 (F), subjected to different doses of N fertilization. ** and $*$ Significant by the F-test, at 1 and $5 \%$ probability, respectively. 
Considering the production volume obtained in the second and third crop years, maintenance fertilization should have been already implemented, but according to the current recommendation (Manual..., 2016), it is still the growth period fertilization. This may limit the yield potential because the recommended amounts of nutrients do not take into consideration the nutrient requirements and transfer to fruit, and therefore it may be underestimated.

Compared to the year 2014, yield reduction was observed in 2015. This was probably due to adverse weather conditions, such as excessive rainfall during the $\mathrm{N}$ application period (August to February). During this period, rainfall was $70 \%$ higher $(1,329 \mathrm{~mm})$ than the historical mean $(750 \mathrm{~mm})$ (Figure 1). Excessive rainfall favors $\mathrm{N}$ leaching and loss of available $\mathrm{N}$ fertilizer. The loamy sand soil with less than $20 \%$ of clay in the orchard also facilitates leaching (Manual..., 2016). Nitrogen loss through leaching in the soil occurs mostly in the form of nitrate $\left(\mathrm{N}^{-\mathrm{NO}_{3}}{ }^{-}\right)$and ammonium $\left(\mathrm{N}-\mathrm{NH}_{4}^{+}\right)$, which are commonly used in fruit tree orchards; however, $\mathrm{N}$ loss also depends on the quantity of applied N, soil type, and rainfall volume (Nielsen et al., 1982; Barlow et al., 2009; Lorensini et al., 2012).

As to fruit mass, in 2013 there was a quadratic effect of increasing $\mathrm{N}$ doses, with an estimated maximum, effective dose of $70 \mathrm{~kg} \mathrm{ha}^{-1} \mathrm{~N}$ (Figure $3 \mathrm{C}$ ), which was similar to that observed for fruit yield in the same year. During the third and fourth years, there was no effect of increasing $\mathrm{N}$ doses on fruit mass. The amount of applied $\mathrm{N}$ was probably insufficient because the plants were larger and had a higher-fruit yield. Therefore, there was an effect of "dilution" of the applied N.

Fruit mass was higher in the first year than in the subsequent years in 'Cascata 1513' (Table 2). Fruit size is defined by genetic characteristics of the plant and by the orchard management system (Giovanaz et al., 2014). In addition, it depends on the load of fruit in the plants, but a relationship between increased yield and reduced fruit size, and vice-versa, is not always observed (Almeida et al., 2014), especially before yield stabilization. Moreover, Mayer et al. (2016) showed that high-density planting did not affect the physical characteristics of fruit, such as mass and diameter, and therefore, did not affect the yield potential of the plants.

The number of fruit in the initial stage of plant development was low in the assessed cycles; however, the effect of the genotypes was already evident at this stage. The number of fruit in 'Cascata 1513' decreased from the first and second years to the third year (Table 2). In 2013 and 2015, there was a quadratic response in the number of fruit to increasing doses of $\mathrm{N}$, and the estimated technical maximum, effective doses were 50 and $82 \mathrm{~kg} \mathrm{ha}^{-1} \mathrm{~N}$, respectively. This result is in agreement with the response reported by Amorim et al. (2015). Nava et al. (2007) note that previous studies had shown that increasing the dose of $\mathrm{N}$ led to an increase of fruit ripening and, therefore, of the number of fruit. However, in the present study, there was no response to increasing doses of $\mathrm{N}$ in 2014, probably because most plants were still in the early vegetative phase, and they were not yet flowering, requiring future assessments. According to Oliveira et al. (2015), only a part of the $\mathrm{N}$ provided by the fertilizer is absorbed by the plants and used to produce fruit because of the dynamics of $\mathrm{N}$ in the soil-plant-atmosphere system. The efficiency of conversion of the applied nutrients into biomass depends on numerous complex processes that, in turn, depend on the plant, the environment, and soil fertility management.

\section{Conclusions}

1. The advanced selections of peach (Prunus persica) trees grown in high-density orchards require a higher dose of $\mathrm{N}$ to show an adequate mineral nutrition and to fulfill their vegetative growth potential and, consequently, the productive efficiency of the crop.

2. The current recommended amount of $\mathrm{N}$ fertilization for peach orchards is suboptimal for a high-density planting system.

\section{Acknowledgments}

To Coordenação de Aperfeiçoamento de Pessoal de Nível Superior (Capes) and to Empresa Brasileira de Pesquisa Agropecuária (Embrapa), for financial support; and to Conselho Nacional de Desenvolvimento Científico e Tecnológico ( $\mathrm{CNPq}$ ), for award for excellence in research.

\section{References}

ALMEIDA, G.K. de; MAGRIN, F.P.; SOLDATELLI, P.; FIORAVANÇO, J.C. Fenologia e produtividade de cultivares de 
pessegueiro. Revista de Ciências Agroveterinárias, v.13, p.255265, 2014.

ALVES, G.; SILVA, J. da; MAY DE MIO, L.L.; BIASI, L.A. Comportamento fenológico e produtivo de cultivares de pessegueiro no município da Lapa, Paraná. Pesquisa Agropecuária Brasileira, v.47, p.1596-1604, 2012. DOI: 10.1590/ S0100-204X2012001100006.

AMORIM, D.A. de; ROZANE, D.E.; SOUZA, H.A. de.; MODESTO, V.C.; NATALE, W. Adubação nitrogenada e potássica em goiabeiras 'Paluma': I. Efeito na produtividade e na qualidade dos frutos para industrialização. Revista Brasileira de Fruticultura, v.37, p.201-209, 2015. DOI: 10.1590/0100-2945051/14.

BARLOW, K.; BOND, W.; HOLZAPFEL, B.; SMITH, J.; HUTTON, R. Nitrogen concentrations in soil solution and surface run-off on irrigated vineyards in Australia. Australian Journal of Grape and Wine Research, v.15, p.131-143, 2009. DOI: 10.1111/j.1755-0238.2008.00042.x.

DELLA BRUNA, E.; BACK, A.J. Adubação nitrogenada em pessegueiros 'Aurora' e 'Chimarrita'. Revista Tecnologia e Ambiente, v.20, p.71-80, 2014. DOI: 10.18616/ta.v2010.1561.

DIAS, M.J.T.; SOUZA, H.A. de; NATALE, W.; MODESTO, V.C.; ROZANE, D.E. Adubação com nitrogênio e potássio em mudas de goiabeira em viveiro comercial. Semina: Ciências Agrárias, v.33, p.2837-2848, 2012. Suplemento 1. DOI: 10.5433/1679-0359.2012v33Supl1p2837.

DOLINSKI, M.A. Produtividade, crescimento vegetativo, doenças e qualidade pós-colheita de pessegueiro adensado com manejos de adubação nitrogenada e de poda verde. 2012. 126p. Tese (Doutorado) - Universidade Federal do Paraná, Curitiba.

FACHINELLO, J.C.; TIBOLA, C.S.; VICENZI, M.; PARISOTTO, E.; PICOLOTTO, L.; MATTOS, M.L.T. Produção integrada de pêssegos: três anos de experiência na região de Pelotas-RS. Revista Brasileira de Fruticultura, v.25, p.256-258, 2003. DOI: 10.1590/S0100-29452003000200018.

FERREIRA, D.F. Sisvar: a guide for its bootstrap procedures in multiple comparisons. Ciência e Agrotecnolgia, v.38, p.109-112, 2014. DOI: 10.1590/S1413-70542014000200001.

FERREIRA， L.V.; CORRÊA, A.P.A.; PICOLOTTO, L.; CANTILLANO, R.F.F.; ANTUNES, L.E.C. Qualidade de pêssegos submetidos à adubação nitrogenada. Revista Iberoamericana de Tecnología Postcosecha, v.17, p.108-115, 2016.

FIDALSKI, J.; AULER, P.A.M. Adubação nitrogenada e precipitação sobre a nutrição e produção de laranjeira 'Valência'. Pesquisa Agropecuária Brasileira, v.42, p.141-146, 2007. DOI: 10.1590/S0100-204X2007000200001.

FREIRE, C.J. da; MAGNANI, M. Adubação e correção do solo. In: RASEIRA, M. do C.B.; PEREIRA, J.F.M.; CARVALHO, F.L.C. Pessegueiro. Brasília: Embrapa, 2014. p.259-281.

GIOVANAZ, M.A.; FACHINELLO, J.C.; GOULART, C.; RADÜNZ, A.L.; AMARAL, P.A.; WEBER, D. Produção e qualidade de pêssegos, cv. Jubileu, com uso de fitorreguladores.
Revista Ceres, v.61, p.552-557, 2014. DOI: 10.1590/0034737X201461040015.

GUARÇONI, A.M.; VENTURA, J.A. Adubação N-P-K e o desenvolvimento, produtividade e qualidade dos frutos do abacaxi 'Gold' (MD-2). Revista Brasileira de Ciência do Solo, v.35, p.1367-1376, 2011. DOI: 10.1590/S0100-06832011000400031.

LEAL, R.M.; NATALE, W.; PRADO, R. de M.; ZACCARO, R.P. Adubação nitrogenada na implantação e na formação de pomares de caramboleira. Pesquisa Agropecuária Brasileira, v.42, p.1111-1119, 2007. DOI: 10.1590/S0100-204X2007000800007.

LEONARDO, F. de A.P.; PEREIRA, W.E.; SILVA, S. de M.; COSTA, J.P. da. Teor de clorofila e índice SPAD no abacaxizeiro cv. Vitória em função da adubação nitrogenada. Revista Brasileira de Fruticultura, v.35, p.377-383, 2013. DOI: 10.1590/ S0100-29452013000200006.

LORENSINI, F.; CERETTA, C.A.; GIROTTO, E.; CERINI, J.B.; LOURENZI, C.R.; DE CONTI, L.; TRINDADE, M.M.; MELO, G.W. de; BRUNETTO, G. Lixiviação e volatilização de nitrogênio em um Argissolo cultivado com videira submetida à adubação nitrogenada. Ciência Rural, v.42, p.1173-1179, 2012. DOI: $10.1590 /$ S0103-84782012005000038.

LORETI, F.; MASSAI, R. State of the art on peach rootstocks and orchard systems. Acta Horticulturae, n.713, p.253-268, 2006. DOI: 10.17660/ActaHortic.2006.713.37.

LORETI, F.; MASSAI, R. The high density peach planting system: present status and perspectives. Acta Horticulturae, n.592, p.377-390, 2002. DOI: 10.17660/ActaHortic.2002.592.52.

MANUAL de calagem e adubação para os Estados do Rio Grande do Sul e de Santa Catarina. 11.ed. Porto Alegre: Sociedade Brasileira de Ciência do Solo, Núcleo Regional Sul, Comissão de Química e Fertilidade do Solo, 2016. 375p.

MARINI, R.P.; REIGHARD, G.L. Crop load management. In: LAYNE, D.R.; BASSI, D. (Ed.). The peach: botany, production and uses. Wallingford: CAB International, 2008. p.289-302. DOI: $10.1079 / 9781845933869.0289$.

MAYER, N.A.; NEVES, T.R. das; ROCHA, C.T.; SILVA, V.A.L. da. Adensamento de plantio em pessegueiros 'Chimarrita'. Revista de Ciências Agroveterinárias, v.15, p.50-59, 2016. DOI: $10.5965 / 223811711512016050$.

MAYER, N.A.; PEREIRA, F.M. Produtividade de pessegueiros 'Aurora-1' em diferentes espaçamentos e métodos de propagação do porta-enxerto 'Okinawa'. Bragantia, v.71, p.372-376, 2012. DOI: $10.1590 / \mathrm{S} 0006-87052012005000026$.

MEDEIROS, B.G. de S.; GOUVEIA, J.P.G. de; ALMEIDA, F. de A.C.; RIBEIRO, C. de F.A.; DUARTE, S.M.A. Características físicas da goiaba (Psidium guajava L.): efeito da adubação nitrogenada. Revista Brasileira de Produtos Agroindustriais, v.6, p.47-53, 2004. DOI: 10.15871/1517-8595/rbpa.v6n1p47-53.

NAVA, G.; NUERNBERG, N.J.; PEREIRA, A.J.; DECHEN, A.R. Adubação de crescimento de macieira $\mathrm{Cv}$. Catarina sobre portaenxerto marubakaido em São Joaquim-SC. Revista Brasileira de Fruticultura, v.29, p.359-363, 2007. DOI: 10.1590/S010029452007000200033. 
NIELSEN, D.R.; BIGGAR, J.W.; WIERENGA, P.J. Nitrogen transport process in soil. In: STEVENSON, P.J. (Ed.). Nitrogen in agriculture soils. Madison: American Society of Agronomy, 1982. p.423-448.

NUNES, J.L. da S.; SOUZA, P.V.D. de; MARODIN, G.A.B.; FACHINELLO, J.C. Incremento no desenvolvimento do portaenxerto de pessegueiro 'Aldrighi' por fungos micorrízicos arbusculares autóctones. Ciência e Agrotecnologia, v.32, p.17871793, 2008. DOI: 10.1590/S1413-70542008000600017.

OLIVEIRA, P.N. de; DOVIS, V.L.; MATTOS JUNIOR, D. de. Nitrogênio na cultura dos citros. Informações Agronômicas, n.151, p.6-14, 2015.

PEREIRA, I. dos S.; NAVA, G.; PICOLOTTO, L.; VIGNOLO, G.K.; GONÇALVES, M.A; ANTUNES, L.E.C. Exigência nutricional e adubação da amoreira-preta. Revista de Ciências Agrárias, v.58, p.96-104, 2015. DOI: 10.4322/rca.1755.

ROCHA, M. da S.; BIANCHI, V.J.; FACHINELLO, J.C.; SCHMITZ, J.D.; PASA, M. da S.; SILVA, J.B. da. Comportamento agronômico inicial da cv. Chimarrita enxertada em cinco portaenxertos de pessegueiro. Revista Brasileira Fruticultura, v.29, p.583-588, 2007. DOI: 10.1590/S0100-29452007000300032.

ROMBOLÀ, A.D.; SORRENTI, G.; MARODIN, G.A.B.; DE PIERI, A.Z.; BARCA, E. Nutrição e manejo do solo em fruteiras de caroço em regiões de clima temperado. Semina: Ciências
Agrárias, v.33, p.639-654, 2012. DOI: 10.5433/1679-0359.2012v3 $3 \mathrm{n} 2 \mathrm{p} 639$.

ROSSI, A. de; FACHINELLO, J.C.; RUFATO, L.; PARISOTTO, E.; PICOLOTTO, L.; KRUGER, L.R. Comportamento do pessegueiro 'Granada' sobre diferentes porta-enxertos. Revista Brasileira de Fruticultura, v.26, p.446-449, 2004. DOI: 10.1590/ S0100-29452004000300018.

SANTOS, H.G. dos; JACOMINE, P.K.T.; ANJOS, L.H.C. dos; OLIVEIRA, V.A. de; OLIVEIRA, J.B. de; COELHO, M.R.; LUMBRERAS, J.F.; CUNHA, T.J.F. (Ed.). Sistema brasileiro de classificação de solos. 2.ed. Rio de Janeiro: Embrapa Solos, 2006. 306p

SETE, P.B.; MELO, G.W.B. de; OLIVEIRA, B.S.; FREITAS, R.F.; DAL MAGRO, R.; AMBROSINI, V.G.; TRAPP, T.; COMIN, J.J.; GATIBONI, L.C.; BRUNETTO, G. Perdas de nitrogênio do solo e resposta do pessegueiro à adição de composto orgânico. Ciência Rural, v.45, p.651-657, 2015. DOI: 10.1590/0103-8478cr20131232.

SOUZA, F.B.M. de; ALVARENGA, Â.A.; PIO, R.; GONÇALVES, E.D.; PATTO, L.S. Produção e qualidade dos frutos de cultivares e seleções de pessegueiro na Serra da Mantiqueira. Bragantia, v.72, p.133-139, 2013. DOI: 10.1590/S0006-87052013005000024.

TAIZ, L.; ZEIGER, E. Fisiologia vegetal. 5.ed. Porto Alegre: Artmed, 2013. 820p.

$\overline{\text { Received on February 10, } 2017 \text { and accepted on May 29, } 2017}$ 